\title{
The Code of Lek Dukagjini in the Prism of the Italian Professor Salvatore Vilari
}

\author{
Prof. Asoc. Dr. Besim Muhadri \\ University of Gjakova "Fehmi Agani", Gjakova, Kosovo \\ Email: besim.muhadri@uni-gjk.org
}

Kosovo

\section{ABSTRACT}

The Kanun of Leke Dukagjini is a collection of Albanian norms and customs with a legal-social character, in several centuries, before and after the life of Leke Dukagjini, which is thought to be a codifier. The laws of the Code have long served as social norms and as a system of self-government that prevailed in the highlands of northern Albania at the time when the region was ruled by the Ottoman Empire. The Code has a fundamental importance in the history of the Albanian people as it is an ancient document.

His first written form refers to Leke Dukagjini, although it is considered to have existed long ago and to belong to the traditions of oral traditions inherited from generation to generation. The Code by Lekë Dukagjini was summarized with notes by Father Shtjefën Gjeçovi during the years 1910-1925 and was published in 1933, after Gjeçov's death. The interests of scholars but also of translators have been constant. It was first translated into Italian, then into Serbian, French, Russian, and English. The English translation, which resonated tremendously, was made in 1989 by Leonard Fox and published in New York.

Numerous scholars from different parts of the world have written about the ancient Albanian Code. One of them is the Italian professor of colonial law at the Royal University of Rome, Salvatore Vilari, who in 1940 published a long study entitled "Albanian customary legal norms-Kanun of Lekë Dukagjini" (Le consuetudini giuridiche dell'Alabania-Il Kanun di Lek Dukagjin), for which we will talk in our paper. In this paper he deals with the origin of the Code of Lek Dukagjini, the influential weight of the Dukagjins, the summary (book) of Father Gjeçov and Nopça, the territorial power of the Kanun, with the basic concepts on the Albanian tribe, the organs of the tribe, the leaders of the tribe, the blood feud and with many elements which characterize this monumental work of Albanians.

\section{Keywords: Salvatore Vilari, Albanian Code, Leke Dukagjini, Albanian prince.}

\section{Introduction}

Shtjefën Gjeçovi, one of the most prominent figures of Albanian culture in the first three decades of the twentieth century, is considered the founder of several fields of culture and Albanian ethnic culture, such as: ethnography, archeology and in prose and poetry. He was killed on October 14, 1929, by the Serbian gendarmerie. His death was not natural, but a violent death, a death by assassination, organized in a well between the villages of Krajk and Zym of Has, Kosovo.

One of these works of this dedicated collector of Albanian customary and doctrinal traditions, was also the Code of Leke Dukagjini, in the collection and codification of which book he, with much effort and dedication, had worked almost a lifetime. Some of the chapters of this work he would publish in the magazine "Hylli i drites" (1913-1914 and 1921-1924. The publication of the work was taken care of by one of the most prominent figures of our literature of that time and friend of Gjeçov, Father Gjergj Fishta, who also wrote the preface of the book.

The publication of the Code of Lekë Dukagjini, in addition to marking a special act for the Albanian spiritual culture, it will also mark the stage of development and social organization of the Albanian people at a certain time. The https://ijbassnet.com/
Code of Lekë Dukagjini, in addition to the Albanian cultural circles of the time, it will arouse great interest among the cultural and academic circles of Europe and, in this case, the Italian ones that were more present in Albania at that time. Thus, immediately after the publication of the Kanun, in 1933, in Italy, respectively in Rome in issues three and four of the magazine "Studi Albanesi" (Albanian Studies), will be published the study of the Italian professor Giuseppe Castaleti, entitled "Customary forms and life social in the Kanun of Lekë Dukagjini". Seven years later, in 1940, the professor of colonial law at the Royal University of Rome, Salvatore Vilari published the study entitled "Customary legal forms of Albania - Kanun of Lekë Dukagjini".

The study of Salvatore Vilari, an interesting work of presentation of the legal and ethnographic values of the Code

"Anyone who goes to Albania or is interested in its affairs, often hears about a code of customary norms, passed down from generation to generation in human memory and deeply rooted in the consciousness of the people; for a code of customary norms called the Code, and of which there are few who know how to give reliable notices. 


\section{CCenter for Promoting Education and Research (CPER) USA}

WwW.cpernet.org

Some have written on this argument, but few provide accurate information on it. These are generally observations, albeit careful and very interesting, by diligent travelers or researchers who take care of describing the phenomenon without investigating its nature and without including it in an organic system.

Moreover, it is about a difficult job that requires a long processing of data and a careful examination of the case study. However, the Code in general serves to express the norms contained in a code written or transmitted between generations, the whole set of customary norms according to which the life of the highland populations of Northern Albania is regulated ... Highlander, to whichever tribe it belongs, when asked about a certain institution, shows its elements and says "This is what the Code loves". The changes and layers that the tribes each on their account, may have made to the Code are not understood as such, so even those who follow a customary norm distinct from that given for the respective case by the Code, pass it on the Code, the source of the validity of the norm and not the assembly of their community.

In a word, the highlanders recognize in the Code the only source of their traditional right. The Code among other things dictates the norms according to which new rules can be followed for the creation of new rules and provides a whole apparatus suitable for this purpose ${ }^{1}$.

These are some of the assessments of the Italian professor of colonial law at the Royal University of Rome, Salvatore Vilari, presented in the introduction of his work entitled "Customary legal norms of Albania The Code of Leke Dukagjini"2, published in 1940. Three years after the publication of Shtjefën Gjeçov's work "The Code of Leke Dukagjini" and one year before it was translated into Italian (1941).

The title of the book "Customary legal norms of Albania", the limited study in Northern Albania, seems to correspond to its structure and purpose, through which the author seeks to present to the reader as an attempt at methodology and an attempt to a deeper study. Vilari intends to make, as he says himself, a simple attempt to present the subject organically, to make the characteristics of particular institutions understandable, to then be able to compare them with those of institutions such of other peoples. The author, thinking that the Code should be studied and evaluated as the law of the tribe, in some chapters, presents the research of a general character, which belongs to the subject of the Code, its origins and history, its importance and validity, and those that belong to the organization of the tribe in Albania.

Having in mind the relevant preliminary observation of the law, it takes into account not only the norms in the

${ }^{1}$ Salavatore Vilari, "Normat zakonore juridike të Shqipërisë- Kanuni i Lek Dukagjinit" (Le consuetudini giuridiche dell'Alabania - Il Kanun di Lek Dukagjini", Roma, 1940, XVIII).

2Normat zakonore juridike të Shqipërisë - Kanuni i Lek Dukagjinit" (Le consuetudini giuridiche dell'Alabania-Il Kanun di Lek Dukagjini"), përkthyer në shqip nga Qemajl Velija dhe i botuar nga shtëpia botuese OMBRA GVG, content of the text of the Code, but also other elements collected by itself, or those that have been elaborated from previous studies.

Vilari himself admits that at the core of his work was the subject of the Code in the Albanian edition of the Franciscan Fathers, provided with an introduction by Father Gjergj Fishta and an unpublished translation by Captain Anxjelko Antiko. However, there have also been attempts to collect data from the oral sources of people, local leaders and highlanders, then data on the whole and specific parts of the Code passed down through the generations, and on other norms that together constitute the totality of local customary norms.

A great help for the author, we see that were the conversations held with Mustafa Kruja, Ernest Koliqi, Maliq Bushati, Tefik Mborje, Terenc Toçi, Emin Toron, Petraq Pepon, Markagjon's, Zef Kadare, Father Zef Valentini, etc., who for at the time they were competent persons and had knowledge of the subject matter, but who also held high social positions at the time the author researched and published his book.

For the books consulted on this occasion, we are giving a separate list; those directly related to our study are few; others need to be known for posing problems. Reading the bibliography, he consulted, it can be seen that the figure has gone to 375 bibliographic units.

The book in question by Professor Salvatore Villar is composed of nine chapters. In the first Chapter, "Organization of the tribe", deals with: the origin of the Code of Lek Dukagjini, the influential weight of the Dukagjins, the summary (book) of Father Gjeçov and Nopça, the territorial power of the Kanun, with basic concepts on the Albanian tribe, bodies of the tribe, the chiefs of the tribe, the councils, the assemblies and the forerunners of the Code as well as the laws of Vat'thangan.

Professor Vilari refers to the explanation of the "Law of the Mountains" according to the local concept. According to Vilari, it is a set of customary norms passed down from generation to generation in the memory of man, who at the time he writes was still partially in force in the mountains of Upper Albania, in the areas above Shkodra and the vast territory since the past. she was the mother of the Dukagjins' addiction".

\section{Lekë Dukagjini codifier of the customary law of the mountain population?}

Tradition, says Vilari, calls the law of the highlands after the Code of Lek Dukagjini, that is, of Aleksander Dukagjini, the son of Pali, who lived in the time of Skanderbeg. According to Vilari, Dukagjini, or this powerful gentleman, as Vilari describes him, would codify the customary law of the mountain population, creating perhaps the greatest heritage of the Albanian people. The author also 


\section{CCenter for Promoting Education and Research (CPER) USA}

WWW.cpernet.org

deals with the views of scholars ${ }^{3}$ regarding the name, or "ownership" of the name attributed to this important Albanian document, where it is said that it was named or derived from two tribes: that of Leke and that of Dukagjini, although he rejects such a hypothesis as unfounded and unbelievable and rather believes that the authorship of the Code could be attributed to only one Dukagjini, who in this case is Leka.

To confirm or strengthen this idea, he takes three examples or expressions used in Malësia for the law of Malësia, for the Code of the mountains and its author Lekë as: Kanun of Lekë, Kandun of Lekë, Kanun of Lek Dukagjini and "Kanuni Leke Dukagjini ", where the first three expressions refer to the person of Aleksandër Dukagjini ${ }^{4}$, Lekë, without the name of the tribe, while the last one also refers to the tribe. However, even in this case, Vilari says that there is no clear difference, as in general the highlanders, whether of Lekë or Malcija, are usually kept as descendants of Aleksandër Dukagjini. The author believes in the possibility that before Lek Dukagjini in Albania there were written statues for many small republics, which constituted Albania and that the same are identified with the tribes. He bases this on the statement when he says that he finds them in the works of Milan Shuflaj, in which, as he says, there is talk of lost or hidden statutes, with the statement that in 1389 (the year when the Battle of Kosovo against the Turks took place), when in the Franciscans node 35 of a statue written on papyrus was found. So Vilari goes far in history to trace the roots of the Kanun and its Lord, Lekë.

He also talks about the year 1415, in which year, as he says in his text, the League of Flags of Mirdita was formed, a strong union consisting of twelve thousand armed men, of which Vilari believes or does not excludes the possibility of possessing a single Code, i.e. unified as a law, with rules which had to be observed by the League or the Covenant of the flags or flags of Mirdita.

As another argument for submitting and in support of the theses of the previous codification of the Code, Vilari sees the similarity that the highland law had with the laws of Rome, Byzantium or even the Serbs, as well as with the longobard codex or even any customary Gothic and Norman norms.

He believes that the argument can serve to prove the opposite of what is put forward, since the influence of different rulers can change the habits of a people until their complete change. However, even after such claims he fails to find any written argument to substantiate such a thing, especially the issuance of written laws in the time to which he refers. In a country like Albania, where state authority was lacking, customs and traditions were more valuable than written law.

Vilari thinks that if the peoples who passed through Albania (here we are talking about the invaders), dictated their laws, these are not the laws of the Code; nor can it be conceived, but by those peoples (invaders, my supplement, B.M) a gradual written elaboration of the existing legal principles with those brought by them". As proof ${ }^{5}$ of this he brings the fact that during the Turkish rule, the region remained under the rule of customary law, namely the Code, although at that time there were no lack of bodies of the court of the Ottoman state. According to Villar, what constitutes the moral and legal whole of the Code is the fruit of a later act with a time in which in that particular territory the power of a family was strengthened and the foundations of an organization of a state character were laid.

This is about the Dukagjini family, which when he talks about his study, he says that it is a family with important weight in the history of Albania. A family with an early origin, which is thought to have existed since ancient times, namely since the time of Troy ${ }^{6}$. Here the author enters into the decomposition of the etymology of the surname Dukagjin, where, according to him, it is composed of the Albanian name "Gjin" and a western name "Duk". The author is convinced that on this basis they have gained the noble title outside their land. He also gives us information about the continuity of life and movements of this famous Albanian family. Vilari says that one of this family, who had moved to the Zadrima plain south of Shkodra, had begun his rule in the territory of Albania. It also gives other information about this family, which he says that at the end of the XV century they exercised their power in two territories, which as a natural territorial division had the river Drin. They ruled the territory northeast of Shkodra, over a part of Mirdita and northeast of Lezha in lower Zadrimen, including the territory of Fani in Mirdita.

"The whole territory where the Code has power, belongs to the two branches of the Dukagjins. The customary norms that existed in the two parts, passed down from father to son, were restored, coordinated and made to be respected by Leka III, the most prominent of the Dukagjins, both for this work of his and for the war undertaken against Venice and the Turks, not least notable for his great talents as an organizer and legislator."7

Given all these elements, he does not find in others convincing arguments of not recognizing the authorship of the Code of Alexander (Lek) Dukagini. "All those who have tried to do such a thing, have tried unsuccessfully, because they have not managed to specify the author of the reworking of those principles", claims Vilari. He further claims that even those who do not accept the authorship of Lekë Dukagini for the Kanun, nevertheless admit that its codification took place at the same time.

In this part of his study Vilari refers to G. Volpes who talks about this issue, but who admits that the Code, being a

5 Salvatore Vilari, Normat juridike të Shqipërisë - Kanuni i Lek Dukagjinit, OBRA GVG, Tiranë 2012, f.18 ${ }^{6}$ Hopf: Chronique preromanes'Berlin 1873 sipas referencës autorit Athanas Gegaj në veprën "L'Albanie et l'Invasione Turque au XV siècle, Paris 1931 (cituar sipas Vilarit, f.18).

'Hopf: Chronique preromanes'Berlin 1873 sipas referencës autorit Athanas Gegaj në veprën 'L'Albanie et l'Invasione Turque au XV siècle, Paris 1931, f. 19. 


\section{(C) Center for Promoting Education and Research (CPER) USA}

www.cpernet.org

little work of all and a few of some, had its first creator in Alexander III of Dukagjinis ${ }^{8}$.

Professor Salvatore Vilari rightly states that the Kanun would remain scattered and would undoubtedly be lost, and remain completely unknown if Father Shjefën Konstantin Gjeçovi had not carried out a persistent and dedicated search and would not have started publishing in 1913. of some of his chapters in the magazine "Hylli i Dritës". The author then shows the reasons for the cessation of publication or completion of the work in question, due to the murder or violent death, as he calls it, of Gjeçov by the Yugoslavs on October 14, 1929 near Zym of Hasi where he also served as parish priest. He also tells of the care and publication of this work by the Franciscan fathers in its preparation and publication in 1933 as a posthumous work, which, according to Villar, in the original text is presented with many shortcomings in form and content. This is true, because it had not yet been completed entirely by Gjeçov, who would surely have completed and better prepared it for publication.

Vilari here also mentions the testimony of Petraq Pepo, a teacher from Korça, who worked in Elbasan, evidence that speaks of the existence of another important summary of the Kanun, compiled by Baron Nopça, which at the time Vilari talks about, was owned by Norbert Jokl, professor at the University of Vienna. Vilari expresses regret that he could not provide, to compare the two texts, "either for the authority of the compilers of the two sources, or because the text of Nopça, as far as was known, would be enriched with a detailed study of the author himself."

Then, in this chapter of his book, Vilari, since he considers the Kanun as the corpous juris of the Dukagjini tribe and the corpus juris of the whole Mirdita, deals with other aspects related to it, such as the territorial power of the Code, with the Albanian tribe, the basic concepts for the tribe, the organs of the tribe, with their leaders and other aspects, which make his study very interesting and very important, which enters the studies of foreign authors for a work so monumental and so unique for Albanians, such as the Code of Lekë Dukagjini, collected and codified by Shtjefën Gjeçov.

The second chapter of the first part of the book Vilari deals with issues related to the structure and evolution of the Code of Lekë Dukagjini, in the third chapter on the historical and current value of the Code where customary norms should be distinguished. Another issue addressed by Vilari is the value of the Kanun in ancient times and its foundation and validity as well as recognition in legal terms (implied by the legislation of the state in the force of decree law no. 128 of 1928). Equally important is the aspect of the existence of other Codes. Of particular importance is the linguistic aspect and the importance given by the regime of that time to the institutions of customary law, etc.

In the second book (this is how he conceives it), which consists of nine chapters, the author deals with specific or concrete issues of the Code, which are intertwined within its structure such as: Family (Chapter I), Marriage (Chapter II), with the issue of Property and assets (chapter III), Separation of property and inheritance (chapter IV), Contract and special institutions (chapter V), Norms of criminal character (chapter VI), Blood law (chapter VII), Procedural elements (chapter VIII) to conclude with notes on the law of the Church (chapter IX).

\section{Conclusion}

The work "Legal norms of Albania-The Code of Lek Dukagjini" (Le consuetudini giuridiche dell'Alabania-Il Kanun di Lek Dukagjini), is undoubtedly an important effort and contribution of the author to present the historical, cultural, legal and customary values of Albanians. With the publication of this study, in the 40s of the XX century, another special aspect is marked: That of deepening the interests of foreign scholars in their perception and engagement in the display of the values of the antiquity of the Albanians.

The Code of Lekë Dukagjini, as a summary of Albanian norms and customs of a juridical-social character, is also an important achievement of Albanians in preserving their cultural, national and state identity. Therefore, the interest of Salvatore Vilari for the study and analysis of this work is of special importance. It is no coincidence that he says that: "Everyone who goes to Albania or is interested in its affairs often hears about a code of customary norms, passed down from generation to generation in human memory and deeply rooted in the consciousness of the people; for a code of customary norms called the Code, and of which there are few who know how to give reliable notices. Or: "when it comes to the "Code", it is, also, a difficult job that requires a long processing of data and a careful examination of the case study. 


\section{References and Literature}

Shtjefën K. Gjeçovi. “The Code of Lekë Dukagjinit”, Shkodër 1933.

Gjeçovi, vepra 4, "Rilindja”, Prishtinë, 1985.

The code of Lekë Dukagjini, Albanian Text Collected and Arranget by Shtjefën Gjeçov, Translated, with an Introduction, by Leonard Fox. Gjonleka Publishing Company, New York, 1989.

At Shtjefën K. Gjeçov O.F.M. “Kanuni i Lekë Dukagjinit, Botime françeskane 2018.

Salvatore Vilari, Normat juridike të Shqipërisë - Kanuni i Lek Dukagjinit, OBRA GVG, Tiranë 2012 (Le consuetudini giuridiche dell'Alabania - Il Kanun di Lek Dukagjini”, Roma, 1940, XVIII)

G. Volpe:-Formaxione storia dell' Albania botuar në numrin 16, dhjetor 1939

Besim Muhadri, Shtjefën Gjeçovi dhe Kanuni i Lekë Dukagjinit, Universiteti i Gjakovës “F. Agani”, Gjakovë, 2020. 